\title{
Accountability from Village Democracy Against Corruption: a Case Study
}

\author{
Weihua Liu \\ Macau University of Science and Technology \\ Macau, China
}

\author{
Shaosong Wang* \\ Macau University of Science and Technology \\ Macau, China \\ * Corresponding Author
}

\begin{abstract}
Decentralization of decision-making power from the central government to local governments, and from local government to communities and villages are a salient feature of China's reform. It has invigorated Chinese economy but created rampant corruption at the same time. It has been proved that the increased discretionary power provides opportunities and incentives for local officials to corrupt. Lack of institutional and societal supervisions make it less contained. This paper will discuss how to control local corruption by accountability from village democracy using a case study in Qing County of Heber Province, China. The information and data are collected by interviews of one author in that county.
\end{abstract}

Keywords-accountability; village democracy; local corruption

\section{INTRODUCTION}

Decentralization of decision-making power from the central government to local governments, and from local government to communities and villages are a salient feature of China's reform. It has invigorated Chinese economy but created rampant corruption at the same time.

Following decentralization, local cadres implement policies selectively, especially in the Chinese countryside. Some cadres conscientiously enforce unpopular policies while refusing to carry out other measures that villagers welcome. (O'Brien and $\mathrm{Li}, 1999$ ) For instance, although some provincial governors have sought to make reducing burdens a binding target, they have often failed to persuade officials at lower levels (or even their own deputy governors) to take them seriously. (Li, 1993) Top-down monitoring alone is not enough to supervise local bureaucrats whose every move cannot be observed. Not a few local cadres have become corrupt and high-handed "Local Emperors" (Tu Huangdi).

Some Chinese analysts believe that unless the rural populace is granted a larger role in selecting and assessing local cadres, they argue, it is unlikely that misbehavior can be uncovered and stopped. (Xi, 1993; Li, 1994) However, village election produced little effect on village governance in many areas due to the dysfunctional village governance structure, township re-assertiveness over villages and the village dual-leadership factor. (Tan, 2010) The promotion of village democracy should be complemented by simultaneous improvements in a number of other ears that enhance accountability of local officials, such as village affairs disclosure, and institutionalized participation in democratic decision making. (Su and Yang, 2005). The invention of Qing County is a good case of enforce accountability by promote citizen participation and self-governance.

The Qing County is located in Cangzhou City as shown in "Fig. 1", in the east of Hebei Province of China. The investigators live in Qing County for two weeks. The places of field study in Qing County are selected from Shilou Village, Tasizhuang Village, Hudianzi Village, Beiyu Village, Zhizhuangzi Village, ect, and some officials in the CPC committee of Qing County, grassroots cadres, and some representatives were interviewed.

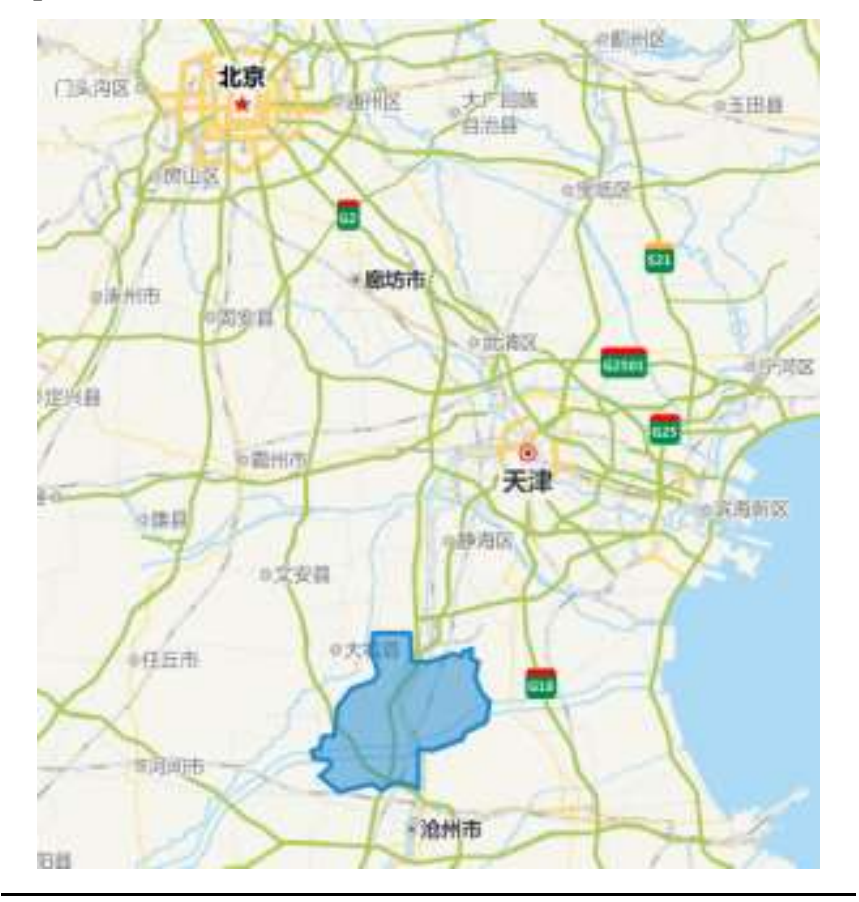

Fig. 1. The location of Qing County.

\section{ACCOUNTABILITY FROM VILLAGE DEMOCRACY}

Qing County conducts local governance reform and created the so-called "Qing County Model". The model has got great achievement in containing corruption and improving local governance. The experience of Qing County 
has attracted the attention of many scholars, and was widely praised by policy makers. A conference "Qing County Village Governance Model - Seminar on Rural AntiCorruption Mechanism" attended by scholars and officials was held in Beijing in the year 2010.

The basic institutions in the villages are the Village Representative Assembly, the Village Party Committee and the Village Committee. The Village Representative Assembly are consisting of village representatives, each directly elected by around 10-15 families. Then the representatives of the whole village elect a chairperson, but the Chairperson of the Assembly cannot be the head of the Village Committee. While the secretary of the Village Party Branch is encouraged to attend the election campaign of the Chairperson of the Assembly. If the secretary fails, s/he should resign his secretary position immediately, because $\mathrm{s} /$ he has lost the popular support of the villagers. All major policies of the village must be determined on the Assembly. At the same time, the CPC Branch shifts from micromanaging village affairs to macro issues and providing suggestions to the Assembly. And the Villagers Committee is transformed to the executive organ of the Assembly as shown in "Fig. 2".

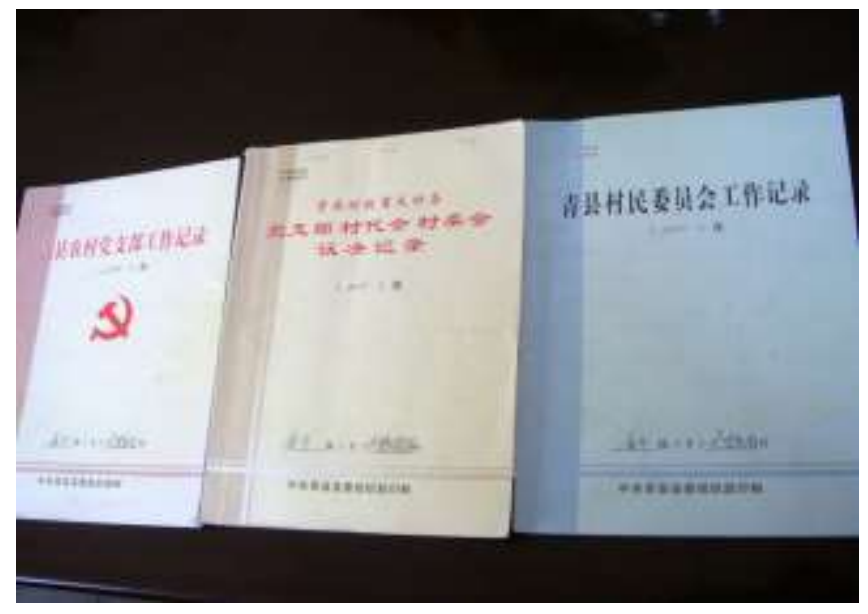

Fig. 2. Work records of the village party committee, the village representative assembly, and the Village Committee in a village in Qing County.

Before 2003, the villagers' committee was elected by the villagers too, and the institution guaranteed the villagers' right of democratic election. But their rights in democratic decision, democratic administration and democratic supervision are short of institutional guarantee. Many cadres committed corruption, and the benefits of villagers were often infringed. And the villagers' financial management group and the village affairs exposure supervision group performed no practical function. The opinions of villagers could not be expressed smoothly to the cadres. The social conflict often raised unrest in rural areas.

The new model inserts community members into the process of governance, and increases the transparency of local decision-making processes, opening the governance affairs to public scrutiny. Through introduction of citizen supervision over the Village Committees, the Qing County
Model also acts as a check to corruption by making village cadres accountable to their constituents. For example, the reception fees were decreased greatly by the new model. In the Big Pigeon Village, the Villager Representative Assembly refused to reimburse some unreasonable fees for dinner, and the Party Secretary Han Zhihua had to pay them by himself, as shown in "Fig. 3".

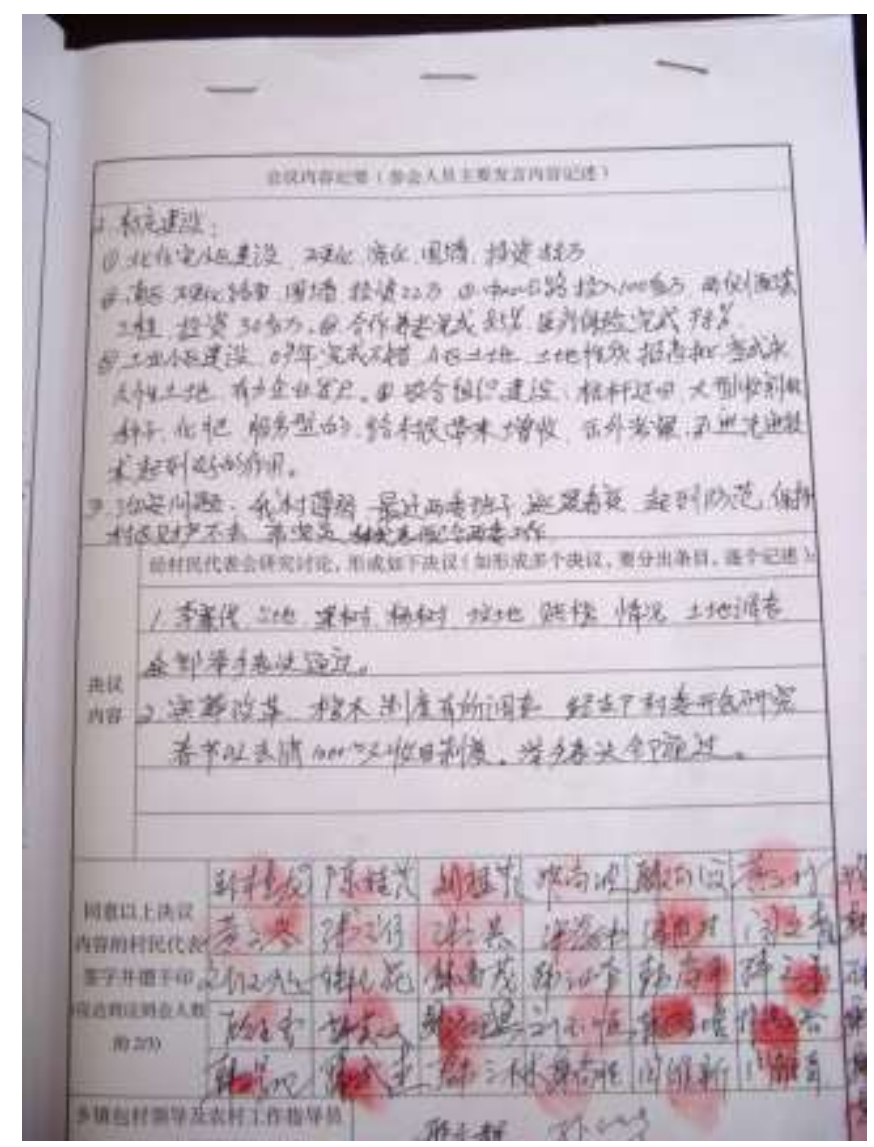

Fig. 3. Part of the record of a meeting of the village representatives in a village in Qing County.

The new model obtained great achievement. One year after the model's introduction, a survey showed that $44.64 \%$ of the respondent agreed that their villages were going better than before the now model, $44.93 \%$ agreed on "well". The cases of complaint letter and visit (Xinfang) were decreased by $11 \%$ from 2003 to 2004 , by $22.7 \%$ from 2004 to 2005 , by $26.8 \%$ from 2005 to 2006. And the collective cases of complaining in Beijing were eliminated. Moreover, the new model has mobilized the villagers to participate in rural development programs. For instance, in 2004, 183 villages built 396.4 kilometers of paved road, which was an increase of 4 to 5 times of previous years. So we can conclude that Qing County's local democracy improved the local governance and then the local economic development.

\section{CONCLUSION}

Citizen participation improved performance and accountability in local governance. The Qing County innovation follows the fourth model of community 
engagement, which are the managerial model, legislative model, limited community participation model and community empowerment model. (Gibson, Lacy, and Dougherty, 2005) It is built around extensive community participation and is designed as an empowerment process to develop a community agenda and engage the residents of the community over a long period of time. The Qing County model was the innovation of the local people and the local cadres in the process of dealing with practical issues. It has lasted for more than ten years.

In the administration innovation of grassroots governance in China, Qing County Model is the closes to western-style democracy. Some officials worried about that this model would yield the leadership position of CPC in rural areas. The villagers' assembly and representative conference has the formal power in the village. And the party organ has been transformed into a power vehicle de facto, contrasting to the case in Wuyi Zhejiang, where the Director of the Supervision Committee was required to be CPC member, and independent monitoring became impossible gradually. (Chen, 2010) The new model compromises the autonomous of village, local governance and party leadership. More practically, the local cadres must be accountable to the Representative Assembly, which reduced corruption greatly.

\section{REFERENCES}

[1] Chen Ningyi (2010): "The Six-Year Experiment of Supervision on Village Cadres in Wuyi Zhejiang"(Zhejiang Wuyi Cunmin Jiandu Cunguan 6 Nian Shiyan), Beijing News (Xin Jiang Bao), October 26th.

[2] Gibson, Pamela, Donald P. Lacy and Michael J. Dougherty (2005): "Improving Performance and Accountability in Local Government with Citizen Participation", The Innovation Journal: The Public Sector Innovation Journal, Vol. 10 (1).

[3] Li Kang (1994): "Grass-roots Government and Grass-roots Community", in Li Xueju et al., eds., Zhongguo Xiangzhen Zhengquan de Xianzhuang yu Gaige (Reform and Current Situation of Chinese Township Political Power), Beijing: Zhongguo Shehui Chubanshe, pp. 265-66.

[4] Li Wenxue (1993): "A Report on Chinese Peasant Burdens" Kaifang Shidai (Open Era), No.5.

[5] O'Brien, Kevin and Lianjiang Li (1999): "Selective Policy Implementation in Rural China", Comparative Politics, January.

[6] Su, Fubing and Dali Yang (2005): "Elections, Governance, and Accountability in Rural China", Asian Perspective, Vol. 29, no.4.

[7] Tanzi, Vito (2000): "Fiscal Federalism and Decentralization: A Review of Some Efficiency and Macroeconomic Aspects" in Proceedings of the Annual World Bank Conference on Development Economics, Washington D.C: The World Bank.

[8] Wang Shaoguang (2008): "The Great Transformation: Two-way Movement in China since the 1980s", Social Sciences in China, No.1.

[9] Xi Ling (1993): "Why Peasant Burdens Have Become a Longstanding, Big, and Difficult Problem", Jiage Yuekan (Prices Monthly), 8 (August). 